\title{
ANALYSIS OF ENERGY PROPERTIES AND EMISSIONS FACTORS OF SELECTED PLANT BIOMASS AND PEAT
}

\section{Grzegorz MAJ}

Department of Power Engineering and Transportation/University of Life Sciences in Lublin, POLAND E-mail of corresponding author: grzegorz.maj@up.lublin.pl

Keywords: biomass, energy properties, emission factors, peat, agroenergy production

\begin{abstract}
The use of agricultural biomass for renewable energy purposes is part of the assumption of sustainable agriculture standards and leads to change current management of biomass from agricultural and forestry production and to development of agroenergy production. Considering the above the paper describes energy properties and emission factors for peat and selected biomass species (wood chips-pine, oat grains, wheat straw) and the mixtures of peat with biomass to demonstrate differences in emissivity in the combustion process by using a mixture of biofuel and fossil fuels. Studies have shown that the net calorific value of the tested materials is similar (about $15 \mathrm{MJ} \cdot \mathrm{kg}^{-1}$ ), but the highest value was recorded for mixtures peat-oat grains and obtained $15.75 \mathrm{MJ}^{\circ} \mathrm{kg}^{-1}$. Ash content was highest for peat $16.58 \%$ but volatile matters content was lowest $50.14 \%$. Wood chips characterized by the highest carbon content of $45.73 \%$, hydrogen at $6.5 \%$ by oat grains, and $2.96 \%$ nitrogen and sulphur $0.25 \%$ by peat. Determined emission rates indicate a reduction of $4-10 \% \mathrm{CO}, 1-5 \% \mathrm{CO}_{2}, 25-58 \% \mathrm{NOx}, 19-61 \% \mathrm{SO}, 26-41 \%$ dust depending on the type of used biomass.
\end{abstract}

\section{INTRODUCTION}

The energy sector plays an important role in European and global industry and finance. The economy of almost every country is determined by the costs and availability of coal, crude oil and natural gas. However, the use of fossil fuels significantly contributes to excessive carbon dioxide emissions into the atmosphere (Nelson et. al., 2014). Studies have shown that in 2010 more than two thirds of total anthropogenic greenhouse gas emissions came from fossil fuel combustion (IPPC, 2014). The main assumption of a low-carbon economy is the achievement of specific economic effects with the least possible use of natural resources and the minimization of environmental pollution (Xie, 2014; Nakomcic-Smaragdakis et al., 2016). The diversification of energy sources is an important issue in implementing a low carbon economy in Europe. Hence, new energy sources are being sought, both for the very efficient ones and those which contribute to the reduction of harmful emissions to the environment.

Peat is produced by the same processes as hard coal and lignite and is the initial stage in the formation of these minerals. Just like hard coal, peat can be used for energy purposes, as fuel in private homes or as fuel in power plants (Ozaist, 2012). The most commonly used for the combustion of peat products are (Ilnicki, 2002): peat fuel, peat briquettes and peat bricks produced by pressing low or transition peat and finally peat charcoal. Power plants also use peat powder (combustion in pulverized and fluidized furnaces), and the latest solution is the combustion of volatile substances released in the gasification process of the raw material (Ozaist, 2012). In power plants using peat deposit, the raw material is usually blended with the other type of fuel especially with biomass (Ozaist, 2012). The production of biofuels from plant biomass compared to the use of conventional energy sources is very beneficial for environmental, economic and energy security reasons (Pimentel and Patzek, 2005). Among the most important environmental benefits of biomass fuels is the significant reduction in greenhouse gas emissions, primarily methane and carbon dioxide (the $\mathrm{CO}_{2}$ released during biomass processing is then absorbed by the growth of the biomass, the emission balance is close 
to zero) and also biodegradability of biomass (Jahirul et al., 2012; Tumuluru et al., 2015; Fournel et al., 2015). Moreover, there is the possibility of efficient management of organic waste from various industrial sectors and no problem with the storage of toxic waste (Jegannathan et. al., 2009; Chisti, 2008).

The aim of the study was to present the energetic properties of selected plant biomass, peat and peat mixtures with the studied biomass and the presentation of differences in emission levels for raw materials and mixtures of biomass with peat.

\section{MATERIAL AND METHODS}

The research focused on the results of a technical and elementary analysis of peat, plant biomass (wheat straw, wood chips and oat grains) and peat mixtures $(1: 1 / \mathrm{m}: \mathrm{m})$ with studied biomass. Studies were performed for the raw material and mixtures samples in order to determine the difference in physicochemical properties of these materials. An assessment of volatile matter (V), ash (A) and moisture (W) content in the tested samples of solid biofuels was done by using thermogravimetric analyser Leco TGA701 with the PN-EN ISO 18123:2016-01, PN-EN ISO 18122:2016-01 and PN-EN ISO 18134-2:2015 standards, respectively. The net calorific value $\left(\mathrm{Q}_{\mathrm{i}}\right)$ was determined according to PN-EN 14918:2010 standard, using a calorimeter LECO AC 600. The content of other combustible solid fractions FC (\%) was determined from Eq. (1):

$$
F C=100-W-A-V
$$

where: $\mathrm{W}$ - moisture content $(\%), \mathrm{A}$ - ash content $(\%), \mathrm{V}$ - content of volatile matter $(\%)$.

The fuel ratio (FR, \%) was calculated according to Eq. (2):

$$
F R=F C / V
$$

In turn, the elemental analysis (coal, hydrogen, nitrogen, sulphur content) was carried out using an automated analyser Leco CHNS 628 in accordance with the PN-EN ISO 16948:2015-07E and PN-EN ISO 16994:2016-10 standards. Oxygen in the samples was determined using the indirect method specified in Eq. (3):

$$
O=100-C-H-N-S-W-A
$$

where: $\mathrm{C}, \mathrm{H}, \mathrm{N}, \mathrm{S}, \mathrm{O}-$ content of elemental carbon, hydrogen, nitrogen, sulphur, and oxygen in the fuel (\%)

The determination of emission levels of individual gases and dust was based on the factor's emission method. The $\mathrm{CO}_{2}$ emission factor was calculated using the calculation method based on the carbon content and calorific value of fuels. For the calculations were used the formulas 3-5 (Borycka, 2008):

$$
\mathrm{SO}_{2}: \quad E=B \cdot w \cdot S
$$

$\mathrm{NO}_{\mathrm{x}} / \mathrm{CO} / \mathrm{CO}_{2}: \quad E=B \cdot w$

Dust:

$$
E=B \cdot w \cdot A \cdot 100 /(100-K)
$$

where: $\mathrm{E}$ - amount of emission $(\mathrm{kg}), \mathrm{B}$ - fuel consumption $(\mathrm{Mg}), \mathrm{S}$ - sulphur content in fuel (\%), A - ash content in fuel (\%), $\mathrm{K}$ - combustible components content in dust (5\% for biomass) $(\%), \mathrm{w}-$ emission ratio. 
The results underwent the statistical analysis conducted by means of the STATISTICA 13 software. The normality of distribution of the properties under consideration was checked by means of the Shapiro -Wilk compliance test. The impact of a certain matter upon the value of incineration gross and net calorific value, ash content, volatile matter, $\mathrm{C}, \mathrm{H}, \mathrm{N}, \mathrm{S}$ content and basic element and heavy metals content in ash was assessed by means of the ANOVA test. Homogeneity of variance was checked by Levene's test. In case of heterogeneity of variance, the F Welch test was performed. The significance level of the diversity was also confirmed by means of the Tukey (HSD) test. All the statistical analyses were conducted at the significance level of $\alpha=0.05$.

\section{RESULTS}

Studies have shown that the highest net calorific value characterized in oat grains 15.72 $\mathrm{MJ} \cdot \mathrm{kg}^{-1}$, and the lowest in wheat straw $15.32 \mathrm{MJ} \cdot \mathrm{kg}^{-1}$ (Table 1) and the difference was approx. $2.5 \%$. Among mixtures, the highest net calorific value was obtained for peat-oat grains $\left(15.75 \mathrm{MJ} \cdot \mathrm{kg}^{-1}\right)$ and the lowest for peat-wheat straw $\left(14.51 \mathrm{MJ} \cdot \mathrm{kg}^{-1}\right)$ with a difference of $7.8 \%$. Intermediate results were recorded for peat and wood chips, while the lowest was peat and wheat straw. Net calorific value of mixtures of peat-wood chips and peat-wheat straw are lower than the net calorific value of raw biomass (and also peat), and the net calorific value of material consisting of peat and oat grains has a slightly higher net calorific value than raw oat grains and peat. In each case, the addition of peat reduced the net calorific value of the mixture relative to raw biomass as opposed to oat grains. The studies have shown the smallest ash content in wood chips, only $0.54 \%$. Also in oat grains, the content of non-combustible substances is small, only $2.71 \%$. The ash content in wheat straw is $8.37 \%$ of its weight, while the ash content of peat is about $16.5 \%$. The best peat additives in this aspect are wood chips and oat grains. Analysis of the test results shows that their admixtures will not significantly affect the amount of ash content and the level of net calorific value. The ash content after combustion process of peat and biomass mixtures is higher each time than in the case of raw wood chips, oat grains or wheat straw. In the first two cases, the percentage of ash increases several times. Nevertheless, given the amount of ash produced during the combustion of biomass and peat mixtures it is much more beneficial than combustion peat itself. In each case, after combustion process such material, less ash is produced than in the case of combustion only peat. The results of the analysis indicate a low coalification of wood biomass, wheat straw and oat grains. In each case, the results of volatile matter content were about $70 \%$. Peat in turn, is a much more metamorphic raw material which the coagulation processes are more advanced in. This is evidenced by the lower volatiles matters content, which fluctuate within $50 \%$. The addition of peat influenced the reduction of the volatiles in mixtures relative to raw wood biomass, oat grains and wheat straw. Materials consisting of peat and wood chips and peat and wheat straw have similar volatile components $(57.46 \%$ and $58.22 \%$ respectively), corresponding to a greater degree of coagulation of raw peat. In the case of oat grainspeat mixtures, the addition of peat had a lesser effect on the amount of gaseous substances emitted during pyrolysis process. There was a decrease in the volatiles relative to oat grains, but the content of the coal (C) in this mixture was the lowest. The percentage share of coal content in the tested materials remained at a similar level, ranging from $41.04 \%$ to $45.73 \%$. It was at the same time the main elementary element of each biomass studied. There was also a divergence in the results of hydrogen testing. The analysed materials differ considerably in terms of the proportion of nitrogen and 
sulphur in the flammable substance. Most of the nitrogen contained peat $(2.96 \%)$ almost six times more than wheat straw $(0.52 \%)$, which was also characterized by a very low sulphur content of only $0.07 \%$. The analysed biomass types exhibited similar technical parameters, as evidenced by the 0.19-0.23 range of the fuel ratio (FR). The low ratio suggests that the fuels were characterised by low content of combustible solids (13-15\%) and high content of volatiles (68-71\%), which is characteristic for the biomass. In the case of peat, the fuel ratio was higher $(0.43)$ than for biomass and mixtures. The mixtures also obtained similar technical characteristics in which the fuel ratio was in the range of 0.29 to 0.33 and content of combustible solids was higher than in the raw biomass (17-19\%), while the volatiles content was lower (57-61\%) but higher than peat $(50.14 \%)$.

Table 1. Physicochemical properties of analysed biomass and peat

\begin{tabular}{|c|c|c|c|c|c|c|c|c|}
\hline Material & $\begin{array}{l}\text { Wood } \\
\text { chips } \\
\text { (pine) }\end{array}$ & $\begin{array}{c}\text { Oat } \\
\text { grains }\end{array}$ & $\begin{array}{l}\text { Wheat } \\
\text { straw }\end{array}$ & Peat & $\begin{array}{l}\text { Peat- } \\
\text { wood } \\
\text { chips } \\
(1: 1) \\
\end{array}$ & $\begin{array}{c}\text { Peat-oat } \\
\text { grains } \\
(1: 1)\end{array}$ & $\begin{array}{c}\text { peat- } \\
\text { wheat } \\
\text { straw } \\
(1: 1)\end{array}$ & $\mathbf{F}$ \\
\hline $\begin{array}{l}\mathrm{Q}_{\mathrm{i}} \\
\left(\mathrm{MJ} \cdot \mathrm{kg}^{-1}\right) \\
\pm \mathrm{S}_{\mathrm{x}} \\
\end{array}$ & $\begin{array}{r}15.42 \mathrm{a} \\
\pm 38.55 \\
\end{array}$ & $\begin{array}{c}15.72 b \pm \\
9.23 \\
\end{array}$ & $\begin{array}{c}15.32 \mathrm{a} \pm \\
5.77\end{array}$ & $\begin{array}{c}15.58 \mathrm{e} \\
\pm 8.08 \\
\end{array}$ & $\begin{array}{r}15.12 \mathrm{~d} \\
\pm 19.62 \\
\end{array}$ & $\begin{array}{r}15.75 b \\
\pm 12.70 \\
\end{array}$ & $\begin{array}{r}14.51 \mathrm{c} \\
\pm 55.24 \\
\end{array}$ & $741.75^{*}$ \\
\hline $\mathrm{W}(\%) \pm \mathrm{S}_{\mathrm{x}}$ & $\begin{array}{l}14.41 \mathrm{f} \\
\pm 0.12 \\
\end{array}$ & $\begin{array}{c}11.81 \mathrm{~d} \pm \\
0.02\end{array}$ & $\begin{array}{c}8.05 b \pm \\
0.02\end{array}$ & $\begin{array}{l}11.52 \mathrm{a} \\
\pm 0.01 \\
\end{array}$ & $\begin{array}{c}13.31 \mathrm{e} \\
\pm 0.04\end{array}$ & $\begin{array}{l}11.51 \mathrm{a} \\
\pm 0.07\end{array}$ & $\begin{array}{c}10.31 \mathrm{c} \\
\pm 0.16 \\
\end{array}$ & $1658.21^{*}$ \\
\hline $\mathrm{A}(\%) \pm \mathrm{S}_{\mathrm{x}}$ & $\begin{array}{l}0.54 \mathrm{a} \\
\pm 0.02 \\
\end{array}$ & $\begin{array}{l}2.71 \mathrm{~b} \\
\pm 0.01 \\
\end{array}$ & $\begin{array}{c}8.37 \mathrm{c} \\
\pm 0.03 \\
\end{array}$ & $\begin{array}{c}16.58 \mathrm{~d} \\
\pm 0.01 \\
\end{array}$ & $\begin{array}{l}10.14 \mathrm{e} \\
\pm 0.05 \\
\end{array}$ & $\begin{array}{l}9.67 \mathrm{f} \\
\pm 0.06 \\
\end{array}$ & $\begin{array}{c}12.19 \mathrm{~g} \\
\pm 0.10 \\
\end{array}$ & $29160.43^{*}$ \\
\hline $\mathrm{V}(\%) \pm \mathrm{S}_{\mathrm{x}}$ & $\begin{array}{c}71.72 \mathrm{a} \\
\pm 0.19 \\
\end{array}$ & $\begin{array}{c}69.71 \mathrm{~b} \\
\pm 0.26 \\
\end{array}$ & $\begin{array}{c}68.65 \mathrm{c} \\
\pm 0.02 \\
\end{array}$ & $\begin{array}{c}50.14 \mathrm{~d} \\
\pm 0.01 \\
\end{array}$ & $\begin{array}{c}57.46 \mathrm{e} \\
\pm 0.06 \\
\end{array}$ & $\begin{array}{l}61.04 \mathrm{f} \\
\pm 0.05 \\
\end{array}$ & $\begin{array}{c}58.22 \mathrm{~g} \\
\pm 0.03\end{array}$ & $11154.22^{*}$ \\
\hline $\mathrm{FC}(\%) \pm \mathrm{S}_{\mathrm{x}}$ & $\begin{array}{c}13.34 \mathrm{~b} \\
\pm 0.33\end{array}$ & $\begin{array}{l}15.77 d \\
\pm 0.03\end{array}$ & $\begin{array}{l}14.94 \mathrm{c} \\
\pm 0.01\end{array}$ & $\begin{array}{c}21.76 \mathrm{e} \\
\pm 0.02\end{array}$ & $\begin{array}{l}19.10 \mathrm{a} \\
\pm 0.07\end{array}$ & $\begin{array}{l}\text { 17.79f } \\
\pm 0.05\end{array}$ & $\begin{array}{l}19.28 \mathrm{a} \\
\pm 0.07\end{array}$ & $1410.66^{*}$ \\
\hline $\mathrm{C}(\%) \pm \mathrm{S}_{\mathrm{x}}$ & $\begin{array}{c}45.73 \mathrm{~d} \\
\pm 0.85 \\
\end{array}$ & $\begin{array}{c}41.86 \mathrm{ab} \\
\pm 0.05\end{array}$ & $\begin{array}{c}41.04 \mathrm{a} \\
\pm 0.05 \\
\end{array}$ & $\begin{array}{c}42.68 \mathrm{bc} \\
\pm 0.02\end{array}$ & $\begin{array}{c}43.28 \mathrm{c} \\
\pm 0.08 \\
\end{array}$ & $\begin{array}{c}42.12 \mathrm{bc} \\
\pm 0.20\end{array}$ & $\begin{array}{c}41.43 a \\
\pm 0.11 \\
\end{array}$ & $52.05^{*}$ \\
\hline $\mathrm{H}(\%) \pm \mathrm{S}_{\mathrm{x}}$ & $\begin{array}{c}5.8 \mathrm{~d} \\
\pm 0.06 \\
\end{array}$ & $\begin{array}{c}6.5 \mathrm{e} \\
\pm 0.02 \\
\end{array}$ & $\begin{array}{l}5.59 \mathrm{~b} \\
\pm 0.01 \\
\end{array}$ & $\begin{array}{l}4.81 \mathrm{c} \\
\pm 0.02 \\
\end{array}$ & $\begin{array}{l}5.13 \mathrm{a} \\
\pm 0.07 \\
\end{array}$ & $\begin{array}{l}5.56 b \\
\pm 0.08 \\
\end{array}$ & $\begin{array}{l}5.19 \mathrm{a} \\
\pm 0.02 \\
\end{array}$ & $324.30^{*}$ \\
\hline $\mathrm{N}(\%) \pm \mathrm{S}_{\mathrm{x}}$ & $\begin{array}{l}0.91 \mathrm{a} \\
\pm 0.01 \\
\end{array}$ & $\begin{array}{l}1.53 \mathrm{~b} \\
\pm 0.02 \\
\end{array}$ & $\begin{array}{l}0.52 \mathrm{c} \\
\pm 0.01 \\
\end{array}$ & $\begin{array}{l}2.96 \mathrm{~d} \\
\pm 0.02 \\
\end{array}$ & $\begin{array}{l}2.21 \mathrm{e} \\
\pm 0.05 \\
\end{array}$ & $\begin{array}{l}1.97 \mathrm{f} \\
\pm 0.08 \\
\end{array}$ & $\begin{array}{l}1.23 \mathrm{~g} \\
\pm 0.04 \\
\end{array}$ & $1024.93^{*}$ \\
\hline $\mathrm{S}(\%) \pm \mathrm{S}_{\mathrm{x}}$ & $\begin{array}{l}0.09 \mathrm{~b} \\
\pm 0.01\end{array}$ & $\begin{array}{l}0.11 \mathrm{a} \\
\pm 0.00\end{array}$ & $\begin{array}{l}0.07 \mathrm{~b} \\
\pm 0.00\end{array}$ & $\begin{array}{l}0.25 \mathrm{~d} \\
\pm 0.01\end{array}$ & $\begin{array}{l}0.16 \mathrm{c} \\
\pm 0.00\end{array}$ & $\begin{array}{l}0.11 \mathrm{a} \\
\pm 0.00\end{array}$ & $\begin{array}{c}0.14 \mathrm{ac} \\
\pm 0.00\end{array}$ & $138.09^{*}$ \\
\hline $\mathrm{O}(\%) \pm \mathrm{S}_{\mathrm{x}}$ & $\begin{array}{c}32.61 \mathrm{e} \\
\pm 0.66 \\
\end{array}$ & $\begin{array}{c}35.56 \mathrm{~b} \\
\pm 0.09 \\
\end{array}$ & $\begin{array}{c}36.42 b \\
\pm 0.05 \\
\end{array}$ & $\begin{array}{l}21.45 \mathrm{c} \\
\pm 0.02 \\
\end{array}$ & $\begin{array}{c}25.94 \mathrm{~d} \\
\pm 0.18 \\
\end{array}$ & $\begin{array}{c}29.18 \mathrm{a} \\
\pm 0.25 \\
\end{array}$ & $\begin{array}{c}29.65 a \\
\pm 0.10 \\
\end{array}$ & $1067.53^{*}$ \\
\hline FR & 0.19 & 0.23 & 0.22 & 0.43 & 0.33 & 0.29 & 0.33 & - \\
\hline
\end{tabular}

$S_{x}$ - standard deviation; * - Significant value of the F test at significance level $\alpha=0.05$; $a-g$ - Significant difference at the level of significance of $\alpha=0.05 ; F-F$ test

The ANOVA test proved that the kind of matter under consideration did have an impact indeed upon of all tested characteristics (Table 1). The Tukey HSD test proved that the properties under consideration are substantially diversified in those groups for majority of the values of $\mathrm{p}<0.05$.

Table 2 shows the results of estimated emission factors for tested materials. It can be seen that levels of carbon monoxide emissions are similar for all raw materials (50-56 $\mathrm{kg} \mathrm{Mg}^{-1}$ ). In the case of carbon dioxide, the highest emission factor was found for wood chips, while the lowest for wheat straw and the difference was 10.24\%. Among mixtures, the highest emissivity of $\mathrm{CO}_{2}$ is the mixture of peat and wood chips, whiles the smallest of peat-wheat straw mixture and is $4.28 \%$ lower. The use of peat mixture with wood chips causes in a $5.34 \%$ reduction in $\mathrm{CO}_{2}$ emissions, $1.30 \%$ peat with oat 
grains, and $2.92 \%$ peat with wheat straw. By analysing $\mathrm{NO}_{\mathrm{x}}$ emissions among raw materials, the highest emissions are peat $(10.45 \%)$ and in biomass group oat grains $(5.39 \%)$.

Table 2. Emission factors of analysed fuels $\left(\mathrm{kg} \cdot \mathrm{Mg}^{-1}\right)$

\begin{tabular}{|l|c|c|c|c|c|}
\hline \multicolumn{1}{|c|}{ Material } & $\mathbf{C O}$ & $\mathbf{C O}_{\mathbf{2}}$ & $\mathbf{N O}_{\mathbf{x}}$ & $\mathbf{S O}_{\mathbf{2}}$ & Dust \\
\hline Wood chips (pine) & 56.34 & 1379.53 & 3.20 & 0.08 & 0.68 \\
\hline Oat grains & 51.58 & 1262.98 & 5.39 & 0.10 & 3.43 \\
\hline Wheat straw & 50.57 & 1238.24 & 1.83 & 0.07 & 10.57 \\
\hline Peat & 52.58 & 1287.51 & 10.45 & 0.26 & 20.94 \\
\hline peat-wood chips (1:1) & 53.32 & 1305.72 & 7.80 & 0.21 & 12.81 \\
\hline peat-oat grains (1:1) & 51.89 & 1270.72 & 6.95 & 0.10 & 12.21 \\
\hline peat-wheat straw (1:1) & 51.04 & 1249.90 & 4.34 & 0.12 & 15.40 \\
\hline
\end{tabular}

The use of peat and biomass mixtures also leads to a reduction in $\mathrm{NO}_{\mathrm{x}}$ emissions compared to raw peat in combustion process, and when it mixed with wood chips, the reduction is $25.36 \%$, while with the oat grains is $33.49 \%$ and with wheat straw is $58.47 \%$. The same situation is in the case of $\mathrm{SO}_{2}$ emissions. The mixture of peat with wood chips is characterized by a lower $\mathrm{SO}_{2}$ emission factor of $19.23 \%$ compared to peat, oats grains by $61.54 \%$, and wheat straw by $53.85 \%$. Mixing peat with biomass also leads to a reduction in dust emission, and for wood chips it is $38.83 \%$ lower, oat grains $41.69 \%$, and wheat with $26.46 \%$ as compared to raw peat.

\section{CONCLUSIONS}

Studies have shown that the most favourable is combustion a mixture of peat and oat grains. The material obtains the highest net calorific value, generating the smallest amounts of ash among all the examined mixtures and almost a twofold lower amount than those formed by the combustion process of peat. The remaining mixtures are less caloric than raw peat, but as a result of their combustion, there is definitely less ash than use only peat. The least favourable was the combustion of a mixture of peat and wheat straw. Net calorific value for this mixture is not only lower than in case of raw peat, but also lower than that recorded during the combustion of wheat straw. The addition of peat to each biomass resulted in an increase in ash content compared to the incineration of only biomass (the most significant increase was for peat and wood chips as well as peat and oat grains); however, after biomass combustion there is less ash than after peat combustion. The low-emitting fuel with the smallest ash content is a mixture of peat and oat grains. The content of volatile matters in individual biomass components is similar, while peat carburization processes are much more advanced.

Research also has shown that the addition of biomass to fossil fuel which is peat, results in lower emission factors. It should be emphasized that the most favourable indicators were noted for $\mathrm{NO}_{\mathrm{x}}$ and $\mathrm{SO}_{2}$, where the emission reductions were $61.54 \%$ and $41.69 \%$, respectively, for the addition of oat grains. The addition of biomass to peat in the combustion process also contributes to dust emission reduction of up to $41.69 \%$ in the case of oat grains. Therefore, it should be pointed out, that the addition of biomass to fossil fuel in the form of peat contributes to the reduction of pollutant emissions in the combustion process.

In conclusion, new biomass management systems from agricultural and forestry production should be sought, which will contribute to the development of agroenergy 
production. The use of agricultural biomass for renewable energy purposes is part of the assumption of sustainable agriculture standards by the possibility of using waste biomass from agricultural production. Exploiting agro-biomass for energy purposes as a supplement to the fossil fuels will primarily contribute to reducing the consumption of conventional fuels and consequently reducing greenhouse gas emissions and harmful emissions to the environment during their combustion.

\section{REFERENCES}

Borycka, B. (2008). Commodity Study on Food and Energy Utilization of Rich-Food Waste of the Fruit and Vegetables Industry. Monograph. Publisher Radom University of Technology, Radom, Poland.

Chisti, Y. (2008). Biodiesel from microalgae beats bioethanol. Trends in biotechnology, 26(3), 126-131.

Fournel, S., Palacios, J. H., Morissette, R., Villeneuve, J., Godbout, S., Heitz, M., \& Savoie, P. (2015). Influence of biomass properties on technical and environmental performance of a multi-fuel boiler during on-farm combustion of energy crops. Applied Energy, 141, 247-259.

Ilnicki, P. (2002). Peat bogs and peat. University Publisher University of Agriculture in Poznań

IPCC, (2014). In: Edenhofer, O., Pichs-Madruga, R.P., Sokona, Y., Farahani, E., Kadner, S., Seyboth, K. (Eds.), Climate Change 2014 - Mitigation of Climate Change: Contribution of Working Group III to the Fifth Assessment Report of the Intergovernmental Panel on Climate Change. Cambridge University Press, Cambridge.

Jahirul, M. I., Rasul, M. G., Chowdhury, A. A., \& Ashwath, N. (2012). Biofuels production through biomass pyrolysis - a technological review. Energies, 5(12), 4952-5001.

Jegannathan, K. R., Chan, E. S., \& Ravindra, P. (2009). Harnessing biofuels: A global Renaissance in energy production? Renewable and Sustainable Energy Reviews, 13(8), 2163-2168.

Nakomcic-Smaragdakis, B., Cepic, Z., \& Dragutinovic, N. (2016). Analysis of solid biomass energy potential in Autonomous Province of Vojvodina. Renewable and Sustainable Energy Reviews, 57, 186191.

Nelson, D., Herve-Mignucci, M., Goggins, A., Szambelan, S. J., Vladeck, T., \& Zuckerman, J. (2014). Moving to a low-Carbon Economy: The Impact of policy pathways on fossil fuel Asset Values. CpI Energy Transition Series, 1-47.

Ozaist, G., (2012): Energy from the peat bog. Polish Energy, 7, 22-23 (in Polish)

Pimentel, D., \& Patzek, T. W. (2005). Ethanol production using corn, switchgrass, and wood; biodiesel production using soybean and sunflower. Natural resources research, 14(1), 65-76.

Tumuluru, J. S., Lim, C. J., Bi, X. T., Kuang, X., Melin, S., Yazdanpanah, F., \& Sokhansanj, S. (2015). Analysis on storage off-gas emissions from woody, herbaceous, and torrefied biomass. Energies, 8(3), 1745-1759.

Xie, H. (2014). Legal regulation of low-carbon economy. IERI Procedia, 8, 170-175.

PN-EN ISO 18123:2016-01 Solid fuels - Determination of volatile content by gravimetric method.

PN-EN ISO 18122:2016-01 Solid fuels - Determination of ash content by gravimetric method.

PN-EN ISO 18134-2:2015 Solid fuels - Determination of moisture content.

PN-EN 14918:2010 Solid biofuels - Determination of net calorific value. 